\title{
Pengembangan Lembar Kerja Siswa Model Hannafin And Peck untuk Meningkatkan Hasil Belajar
}

\author{
Indri Yuli Yanti \\ Universitas Pendidikan Ganesha \\ E-mail: yuliyantiindri@yahoo.co.id \\ I Ketut Pudjawan \\ Universitas Pendidikan Ganesha \\ E-mail: Ketut.Pudjawan@undiksha.ac.id \\ Ignatius I Wayan Suwatra \\ Universitas Pendidikan Ganesha \\ E-mail:ignatiusiwayan.suwatra@undiksha.ac.id
}

\begin{abstract}
Abstrak
Penelitian ini bertujuan (1) Untuk mendeskripsikan rancang bangun pengembangan LKS dengan model Hannafin and Peck, (2) Untuk mengetahui kualitas hasil pengembangan LKS model Hannafin and Peck, (3) Untuk mengetahui efektivitas LKS IPA model Hannafin and Peck. Metode pengumpulan data, yaitu: metode kuisioner, dan tes pilihan ganda. Analisis data menggunakan deskripstif kualitatif, kuantitatif dan statistik inferensial/induktif uji-t.(1) Rancang Bangun pengembangan LKS, meliputi 3 tahapan: Analisis kebutuhan, perancangan, pengembangan, implementasi, dan evaluasi). (2) LKS yang valid: (a) hasil review ahli isi mata pelajaran menunjukkan sangat baik (100\%), (b) hasil review ahli desain pembelajaran menunjukkan baik (86\%), (c) hasil review ahli media pembelajaran menunjukkan sangat baik $(91 \%)$, (d) hasil review uji coba perorangan menunjukkan sangat baik $(98 \%)$, (e) hasil review uji coba kelompok kecil menunjukkan sangat baik $(97,5 \%)$, (f) hasil review uji coba lapangan menunjukkan sangat baik $(92,7 \%)$. (3) hasil belajar IPA ( $\mathrm{t}_{\text {hitung }}=4.077>\mathrm{t}_{\text {tabel }}=$ 1,67155 pada taraf signifikansi $5 \%$ ).
\end{abstract}

Kata kunci: LKS, model Hannafin and Peck, pengembangan

\begin{abstract}
This study aims to (1) describe the design of the development of worksheets with Hannafin and Peck models, (2) determine the quality of the development of Hannafin and Peck LKS models, (3) determine the effectiveness of the Natural Science Worksheet Letters Hannafin and Peck models. Data collection methods, namely: questionnaire method, and multiple choice tests. Data analysis using descriptive qualitative, quantitative and inferential/inductive statistical t-test . (1) Design and Development of worksheets, includes 3 stages: Requirement analysis, design, development, implementation, and evaluation). (2) valid worksheet: (a) the results of the expert review of the subject matter was good (100\%), (b) the results of the learning design expert review was good (86\%), (c) the results of the learning media expert review was good $(91 \%)$, (d) the results of the individual trial review was good (98\%), (e) the results of the small group trial review was good (97.5\%), (f) the results of the field trial review was good $(92.7 \%)$. (3) science learning outcomes (tcount $=4.077>$ ttable $=$ 1.67155 at the $5 \%$ significance level).
\end{abstract}

Keywords: LKS, Hannafin and Peck's model, development

\section{Pendahuluan}

Pendidikan adalah usaha sadar dan terencana untuk mewujudkan suasana belajar dan proses pembelajaran agar peserta didik secara aktif mengembangkan potensi dirinya untuk memiliki kekuatan spiritual keagamaaan, pengendalian diri, kepribadian, kecerdasan, akhlak mulia, serta ketrampilan yang diperlukan dirinya, masyarakat, bangsa, dan Negara. Pendidikan adalah usaha sadar dan terencana untuk mewujudkan suasana belajar dan proses pembelajaran agar peserta didik secara aktif mengembangkan potensi diri (Sanjaya, 2019). Pendidikan merupakan pemegang peranan yang sangat penting bagi kelangsungan kehidupan manusia. Dengan demikian, bagaimanapun sederhananya peradaban suatu masyarakat, didalamnya terjadi atau berlangsung suatu proses pendidikan. Karena itulah sering dinyatakan pendidikan telah ada sepanjang peradaban umat manusia (UU No. 
20 Tahun 2003). Berbicara tentang pendidikan tentunya tidak jauh dari kata proses belajar, proses belajar mengajar, dan media pembelajaran.

Muhibbin (2014:87) mengatakan belajar adalah kegiatan yang berproses dan merupakan unsur yang sangat fundamental dalam penyelenggaraan setiap jenis dan jenjang pendidikan. Ini berarti bahwa berhasil atau gagalnya pencapaian tujuan pendidikan itu sangat bergantung pada proses belajar yang dialami siswa, baik ketika ia berada disekolah maupun dilingkungan rumah atau keluarga sendiri.

Pembelajaran merupakan suatu sistem yang memiliki komponen-komponen pembelajaran, (1) peserta didik, (2) proses pembelajaran, (3) lulusan dengan kompetensi yang diharapkan, (4) pendidik, (5) kurikulum dan (6) bahan pembelajaran, komponen tersebut saling berkaitan dan terintegrasi menjadi satu fungsi dalam mencapai tujuan, sehingga seluruh komponen haruslah diperhatikan jika ada salah satu komponen tidak terintegrasi dengan tepat maka tujuan pembelajaran tidak tercapai secara optimal (parmiti 2014)

Proses pembelajaran dibangun berdasarkan strategi pembelajaran tertentu. Strategi pembelajaran yang efektif adalah pembelajaran yang mampu membawa peserta didik mencapai tujuan/kompetensi yang diharapkan. Untuk menciptakan proses pembelajaran yang efektif Smaldino et al (dalam parmiti, 2014) menyatakan ada beberapa hal yang perlu di perhatikan yaitu, (1) peran aktif siswa, (2) pemberian latihan, (3) perhatian terhadap adanya perbedaan individual, (4) pemberian umpan balik, dan (5) penerapan pengetahuan dan keterampilan dalam situasi nyata.

Lembar Kerja Siswa berisi serangkaian kegiatan dasar yang harus dilakukan Lembar Kerja Siswa berisi serangkaian kegiatan dasar yang harus dilakukan oleh siswa dalam upaya memaksimalkan pemahaman akan kemampuan dasar pembentukan siswa dalam indikator pencapaian hasil pembelajaran yang sesuai yang harus ditempuh". Lembar kerja siswa adalah upaya guru untuk membimbing siswa secara terstruktur, dimana kegiatan tersebut memberi insentif bagi siswa untuk belajar. Sudah diketahui bahwa para guru diwajibkan untuk menyelesaikan tugasnya dan peran mereka harus menjadi motivator dalam proses belajar mengajar sehingga siswa dapat membangun pengetahuan mereka sendiri melalui berbagai kegiatan dalam kegiatan belajar. Dengan menggunakan lembar kerja siswa dalam proses pembelajaran, siswa diharapkan untuk belajar materi pelajaran secara mandiri.

Lembar Kerja Siswa (LKS) pada umumnya dibeli dan bukan dibuat sendiri oleh guru. Padahal, LKS bisa dibuat sendiri dan bisa jauh lebih menarik serta kontekstual sesuai situasi dan kondisi sekolah ataupun lingkungan sosial budaya siswa. Untuk itu, peneliti dan guru hanya perlu memahami lima point penting berikut ini, yaitu: pengertian Lembar Kegiatan Siswa (LKS), fungsi, tujuan, dan kegunaan LKS dalam pembelajaran tematik, jenis-jenis LKS, unsur-unsur LKS sebagai bahan ajar, langkah-langkah aplikatif membuat LKS, dan mengembangkan LKS menjadi "kaya manfaat" (dalam prastowo 2014: 268). Lembar kerja siswa adalah lembaran-lembaran berisi tugas yang harus dikerjakan oleh siswa. LKS biasanya berupa petunjuk dan langkahlangkah untuk menyelesaikan suatu tugas. Bentuk-bentuk LKS terdiri dari LKS eksperimen berupa lembar kerja yang memuat petunjuk praktikum yang menggunakan alat-alat dan bahan-bahan. LKS non eksperimen berupa lembar kegiatan yang memuat teks yang menuntut siswa melakukan kegiatan diskusi suatu materi pelajaran. Lembar Kegiatan Siswa adalah panduan siswa yang digunakan untuk melakukan kegiatan penyelidikan atau pemecahan masalah. Lembar Kegiatan Siswa dapat berupa panduan untuk latihan pengembangan aspek kognitif maupun panduan untuk pengembangan semua aspek pembelajaran dalam bentuk panduan eksperimen atau demonstrasi. Penggunaan media memberikan manfaat dalam proses pembelajaran, hal ini dikemukakan oleh Arsyad 2011 antara lain yaitu, (1) Media pembelajaran dapat memperjelas penyajian pesan dan informasi sehingga proses belajar semakin lancar dan meningkatkan hasil belajar, (2) Media pembelajaran dapat meningkatkan motivasi siswa, dengan mengarahkan perhatian siswa sehingga memungkinkan siswa belajar sendiri-sendiri sesuai kemampuan dan minatnya, (3) Media pembelajaran dapat mengatasi keterbatasan indera, ruang, dan waktu, (4) Media pembelajaran dapat memberikan kesamaan pengalaman kepada siswa tentang peristiwa-peristiwa di lingkungan mereka, serta memungkinkan terjadinya interaksi langsung dengan guru, masyarakat, dan lingkungannya.

Melihat pengertian tentang LKS secara garis besarnya yaitu bahan ajar Menurut Ernawati, dkk (dalam jurnal Biotek, 2017) bahwa Lembar kerja siswa dapat mempermudah siswa supaya memahami materi yang diberikan, kaya akan tugas-tugas sehingga peserta didik dapat berlatih dan melatih kemandirian belajar siswa, sehingga dengan adanya bahan ajar seperti Lembar Kerja Siswa $(L K S)$ masih terdapat beberapa hambatan bagi peserta didik agar memahami materi pelajaran. Disebabkan karena penggunaan bahasa yang digunakan kurang komunikatif artinya kata yang digunakan tidak dapat memotivasi peserta didik agar membaca dan menumbuhkan rasa ingin tahu terhadap materi yang dijelaskan. Peran tersebut maka pengembangan LKS sangatlah tepat guna memfasilitasi proses pembelajaran untuk meningkatkan hasil belajar siswa. Penggunaan media yang masih sangat konvensional seperti papan tulis dan, dirasakan kurang efisien, baik efisien waktu saat penggunaan, efisien dalam pembelajaran, dan efisien dana. Hal ini sangat berpengaruh terhadap minat dan motivasi siswa untuk belajar. Rencana pengembangan Lembar Kerja Siswa (LKS) ini akan disajikan dengan model pengembangan Hannafin and Peck, karena melalui Lembar Kerja Siswa $(L K S)$ dengan menggunakan model pengembangan Hannafin and Peck peserta didik akan berperan mandiri dan bertanggung jawab mengenali dan 
menemukan informasi, mengolah, dan mengambil keputusan, serta memecahkan masalah secara kreatif dengan melakukan percobaan eksperimen untuk memperkuat pengetahuan peserta didik terhadap materi pembelajaran

Adapun tahapan analisis kebutuhan pengembangan LKS IPA dengan menggunakan model Hannafin and Peck adalah (1) Tahapan pertama Fase pertama dari model Hanafin dan Peck merupakan analisis kebutuhan (Need Assessment). Pengertian analisis kebutuhan dalam konteks pegembangan kurikulum menurut John McNeil ialah : 'the process by which one defines educational needs and decides what their priorities are'. Artinya, bahwa analisis kebutuhan adalah sebuah proses yang didefinisikan sebagai suatu kebutuhan pendidikan dan ditentukan sesuai dengan prioritasnya. Sehingga pada intinya, proses ini adalah proses yang menentukan hal utama dari yang dibutuhkan dalam suatu pendidikan, (2) Fase kedua dari Hanafin dan Peck adalah fase desain (design). Hanafin dan Peck menyatakan bahwa didalam fase desain bertujuan untuk mengidentifikasikan dan mendokumenkan kaidah yang paling baik supaya dapat mencapai tujuan dalam pembuatan media tersebut. Dalam dokumen tersebut dapat berupa story board. sehingga dalam fase kedua ini, tidak lupa dilakukan tes atau penilaian sebelum dilanjutkan ke fase pengembangan dan implementasi. (Afandi dan Badarudin, 2011), (3) Fase terakhir dari model Hanafin dan Peck merupakan suatu pengembangan dan implementasi. Hanafin dan Peck menyatakan bahwa aktivitas yang dilakukan pada fase ini adalah penghasilan diagram alur, pengujian, serta penilain formatif dan sumatif. Penilaian formatif adalah penialain yang dijalankan saat proses pengembangan media berlangsung, sedangkan pada penilaian sumatif yang dijalankan pada akhir proses. Sehingga pada fase ini media dikembangkan dan pembelajaran dilaksanakan sesuai dengan tujuan yang telah dibuat berdasarkan analisis kebutuhan dan desain yang telah dijalankan.

Pada saat melaksanakan observasi dan wawancara dengan salah narasumber yang bernama Ibu Putu Mira Ariyanti, S.Pd., yang merupakan salah satu guru di SD Negeri 5 Kampung Baru, beliau juga merupakan wali kelas IV SD Negeri 5 Kampung Baru. Wawancara tersebut dilaksanakan pada tanggal 4 Januari 2019, Saat beliau menjelaskan terkait dengan proses pembelajaran guru, terkadang masih menggunakan media dalam mata pelajaran lain, itupun jika ada media yang sesuai dengan materi saat itu. Selain itu narasumber juga mengatakan terkadang kesulitan menyampaikan materi kepada peserta didik padahal materi tersebut sangat dibutuhkan oleh peserta didik untuk dipelajari saat berada di rumah agar menambah wawasan serta pengetahuan yang lebih, narasumber juga berharap agar media tersebut dapat berguna untuk menambah wawasan peserta didik serta melatih daya ingat dan tidak hanya digunakan di sekolah saja melainkan bisa dibawa kerumah.

Berdasarkan hasil wawancara dengan Ibu Putu Mira Ariyanti, mengatakan bahwa pengembangan bahan ajar cetak seperti Lembar Kerja Siswa (LKS), sangat dibutuhkan oleh peserta didik dan guru karena membutuhkan media pembelajaran cetak dan bahan pembelajaran yang relevan. Penggunaan LKS dalam proses pembelajaran dapat meningkatkan efisiensi, meningkatkan motivasi, memfasilitsi belajar aktif, memfasilitasi belajar eksperimental, konsisten dengan belajar yang berpusat pada siswa dan memandu untuk belajar lebih baik. Kenyataan di kelas IV, ternyata masih banyak peserta didik yang mendapat nilai rendah. Ini dlihat dari hasil wawancara dengan ibu Putu Mira Ariyanti, siswa di kelas IV dalam kemampuan belajar IPA ada yang memiliki kemampuan yang cukup untuk memahami pembelajaran dan sebagian belum memahami pembelajaran tersebut. Berdasarkan hasil angket/kuisioner diperoleh nilai UTS yang masih banyak di bawah rata-rata KKM, hal ini disebabkan karena banyaknya siswa menganggap mata pelajaran IPA yang menakutkan dikalangan siswa kelas IV SD karena bagi mereka pelajaran IPA sangat sulit dan terkadang tidak mudah dipahami dan membingungkan siswa, Rendahnya hasil pembelajaran siswa disebabkan oleh pembelajaran yang tidak menarik dan kurang berkualitas.

Sesuai dengan kebutuhan guru dalam mengatasi permasalahan dalam proses pembelajaran pada mata pelajaran IPA, dipandang perlu adanya suatu inovasi baru dalam pengembangan sistem pembelajaran yang lebih menarik, interaktif dan efektif serta efisien dalam pemanfaatannya. Sehubungan dengan hal tersebut, dipandang perlu untuk mengembangkan Media cetak yaitu Lembar Kerja Siswa $(L K S)$ Untuk Meningkatkan Hasil Belajar Siswa serta minat belajar pada Mata Pelajaran IPA Kelas IV di SD Negeri 5 Kampung Baru, selain dari itu dapat menambah koleksi LKS di sekolah terutama di kelas IV.

\section{Metode}

Jenis penelitian ini adalah penelitian pengembangan. Populasi dalam penelitian ini adalah seluruh siswa kelas IV SD Negeri 5 Kampung Baru yang berjumlah 30 siswa. Prosedur pengembangan yang digunakan mengacu pada model pengembangan yang dipilih. "Model Pengembangan Hannafin and Peck terdiri atas Tiga langkah, yaitu (1) Analisis kebutuhan (Analysis), (2) perancangan (design), (3) Pengembangan (development) implementasi (implementation), dan evaluasi (evaluation)".

Penelitian ini menggunakan dua metode pengumpulan data untuk menjawab permasalahan mengenai rancang bangun pengembangan Lembar Kerja Siswa dengan model Hannafin and Peck. Hasil uji coba Lembar Kerja Siswa dengan model Hannafin and Peck serta efektivitas Lembar Kerja Siswa gan model Hannafin and Peck yaitu metode kuesioner/angket dan tes. (1) Metode kuesioner/angket merupakan cara memperoleh atau mengumpulkan data dengan mengirimkan suatu daftar pertanyaan/pernyataan-pernyataan kepada responden/subjek penelitian (Agung, 2014:99). (2) Metode tes tertulis merupakan cara mengetahui pengetahuan, 
keterampilan, intelegensi atau kemampuan yang dimiliki oleh siswa dengan menggunakan serentetan pertanyaan yang berupa tes objektif (Agung, 2014:240). Instrumen yang digunakan untuk mengumpulkan data dalam penelitian pengembangan ini adalah (1) lembar kuesioner (angket) dan (2) soal-soal tes pilihan ganda.

Analisis ini digunakan untuk mengetahui tingkat efektifvitas produk terhadap hasil belajar siswa SD Negeri 5 Kampung Baru kelas IV sebelum dan sesudah menggunakan produk pengembangan Lembar Kerja Siswa. Data uji coba kelompok sasaran dikumpulkan dengan menggnakan pre-test dan post-test terhadap materi pokok yang diujicobakan.

Hasil pre-test dan post-test kemudian dianalisis menggunakan uji-t untuk mengetahui perbedaan antara hasil pre-test dan post-test. Pengujian hipotesis digunakan uji-t berkorelasi dengan bantuan microsoft exel dan pemutakhiran hasil dengan perhitungan manual. Sebelum melakukan uji hipotesis (uji-t berkorelasi) dilakukan uji prasyarat (normalitas dan homogenitas).

\section{Hasil dan Pembahasan}

Uji normalitas data dilakukan untuk menyajikan bahwa sampel benar-benar berasal dari populasi yang berdistribusi normal. Distribusi normal artinya data penelitian membentuk kurva norma (lonceng), sehingga perbedaan yang terjadi memang akibat perlakuan bukan perbedaan yang ada pada sampel. Uji normalitas data dilakukan terhadap 30 peserta didik dari hasil belajar IPA peserta didik yang diperoleh dari dua tahap yaitu: (1) Pretest (hasil belajar IPA peserta didik yang mengikuti pembelajaran tanpa menggunakan LKS IPA dengan model pengembangan Hannafin and Peck) dan (2) Posttest (hasil belajar IPA peserta didik yang mengikuti pembelajaran dengan menggunakan LKS IPA dengan model pengembangan Hannafin and Peck). Teknik yang digunakan untuk menguji normalitas data adalah uji Liliefors dengan bantuan microsoft excel. Apabila selisih nilai yang terbesar lebih kecil dari kriteria Liliefors nilai, maka dapat disimpulkan bahwa sebaran data berdistribusi normal. Berikut disajikan tabel 0.1

Tabel 1. Perbandingan Hasil Uji Normalitas Pretest dan Posttest Siswa

\begin{tabular}{ccccc}
\hline No. & Hasil Belajar & L0 & Lt & Keterangan \\
\hline 1. & Pretest & $-0,0602$ & 0,1478 & Normal \\
\hline 2. & Posttest & 0,0058 & 0,1478 & Normal \\
\hline
\end{tabular}

Tabel 1 menunjukkan bahwa hasil uji dari uji normalitas tersebut diperoleh $\mathrm{L} 0=-0,0602<\mathrm{Lt}=0,1478$ maka H0 diterima, sehingga dapat disimpulkan bahwa hasil pretes yang berdistribusi normal. Sedangkan hasil uji posttest dari uji normalitas tersebut diperoleh $\mathrm{L} 0=0,0058<\mathrm{Lt}=0,1478$ maka $\mathrm{H} 0$ diterima, sehingga dapat disimpulkan bahwa hasil posttest yang berdistribusi normal.

Uji homogenitas mencari kelompok data sampel berasal dari populasi yang memiliki variansi yang sama (Candiasa, 2010:192). Homogenitas data dianalisis dengan uji-F, dengan kriteria data homogen jika $F$ hitung $\leq F$ tabel, dan data tidak homogen jika F hitung $\geq$ F. Uji Homogenitas ini dilakukan untuk mengetahui apakah kedua

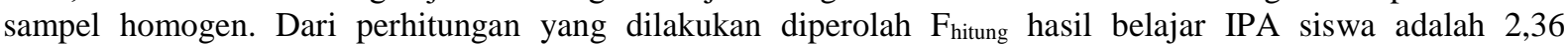
sedangkan $\mathrm{F}_{\text {tabel }}$ dengan $\mathrm{db}_{\text {pembilang }}=29, \mathrm{db}_{\text {penyebut }}=29$ dan taraf signifikan $5 \%$ adalah 1,86 . Hal ini berarti $\mathrm{F}_{\text {hitung }}$ lebih kecil dari $F_{\text {tabel }}(1,22<1,86)$ sehingga varians data hasil belajar IPA kedua kelompok adalah homogen. Setelah diperoleh hasil uji prasyarat analisis data, dilanjutkan dengan pengujian hipotesis penelitian. Pengujian hipotesis tersebut dilakukan dengan menggunakan uji-t sampel independent (tidak berkorelasi) dengan rumus polled varians dengan kriteria $\mathrm{H}_{0}$ tolak jika $\mathrm{t}_{\text {hitung }}>\mathrm{t}_{\text {tabel }}$ dan $\mathrm{H}_{0}$ terima jika $\mathrm{t}_{\text {hitung }}<\mathrm{t}_{\text {tabel }}$. Hasil analisis uji-t diperoleh $\mathrm{t}$ hitung $=20.04$, sedangkan $\mathrm{t}_{\text {-tabel }}$ dengan $\mathrm{db}=(\mathrm{n} 1+\mathrm{n} 2)-2=58$ pada taraf signifikansi $5 \%=1,67155$. Hasil ini menunjukkan bahwa t-hitung > t- tabel. Oleh karena itu dapat dinyatakan bahwa H0 yang menyatakan bahwa LKS dengan menggunakan model pengembangkan Hannafin and Peck efektif diterapkan dalam mata pelajaran IPA siswa kelas IV Tahun Pelajaran 2019/2020 di SD Negeri 5 Kampung Baru.

Oleh karena $\mathrm{t}$ hitung $>\mathrm{t}$ tabel, maka dapat disimpulkan bahwa nilai posttest lebih baik atau bagus dibandingkan dengan nilai pretest. Sehingga dapat diinterpretasikan bahwa dengan menggunakan Lembar Kerja Siswa IPA dengan model pengembangan dapat meningkatkan hasil belajar IPA.

Rancang bangun Lembar Kerja Siswa dengan model pengembangan Hannafin and Peck, Penelitian Pengembangan Lembar Kerja Siswa dengan menggunakan model pengembangan Hannafin and Peck pada materi menerapkan selalu berhemat energi untuk siswa kelas IV di SD Negeri 5 Kampung Baru. Langkahlangkah pengembangan Lembar Kerja Siswa seseuai dengan model Pengemangan Hannafin and Peck. (1) Tahap analisis kebutuhan (2) Tahap Design (Perancangan), (3) Tahap pengembangan dan implementasi. Lembar Kerja Siswa dengan model pengembangan Hannafin and Peck yang dikembangkan terdiri dari 3 kegiatan belajar yang dikemas menjadi satu Lembar Kerja Siswa, pada setiap kegiatan belajar.

Lembar Kerja Siswa yang dikembangkan memiliki format yang berbeda pada LKS umumnya yaitu: (1) Sebelum mulai materi (judul, prakata, daftar isi, indikator, tujuan pembelajaran, dan petunjuk Lembar Kerja Siswa), (2) Saat penyampaian materi (kompetensi dasar, materi pokok, uraian materi, dan latihan atau tugas) dan (3) Setelah penyampaian materi (tes mandiri, post test). Pada Lembar kerja Siswa ini terdapat beberapa konten 
seperti teks dan gambar yang berkaitan yang diperuntukkan untuk menunjang isi dari Lembar Kerja Siswa ini agar mudah dipahami oleh siswa dan menarik minat belajar siswa.

LKS ini termasuk dalam kategori media cetak berupa praktikum didalam LKS ini terdapat beberapa kegiatan dimana semua kegiatan tersebut berunsur praktikum/percobaan, di dalam LKS ini tidak ada materi yang begitu membahas tentang setiap kegiatan, LKS dengan model pengembangan ini lebih menekankan kepada praktikum dan beberapa pertanyaan setelah melaksanakan praktik, setiap kegiatan di beri kata-kata dan gambar berupa motivasi.

Pengembangan Lembar Kerja Siswa, terdapat kegiatan-kegiatan yang berupa praktik/percobaan yang akan di praktikkan oleh sekelompok peserta didik di dalam kelas dan LKS tersebut disesuaikan dengan desain pesan pembelajaran (Sudarma, dkk., 2015) yaitu: (1) Sampul/cover, pada cover ini dikembangkan sesuai dengan kajian analitis desain pesan buku teks diantaranya dalam pemilihan huruf, dipilih huruf yang mudah dibaca sesuai dengan karakter peserta didik pada permainan edukatif teka-teki silang digunakan font huruf jenis comic san karena merupakan kelompok huruf san serif. (2) Petunjuk penggunaan Lembar Kerja Siswa, disampaikan dengan cara yang sistematis dan mudah dipahami oleh peserta didik. (3) Kompetensi yang akan dicapai, pada bagian ini adalah kompetensi inti dan kompetensi dasar. (4) Tujuan pembelajaran yang akan dipelajari, disusun menggunakan formula ABCD (audience, behavior, condition dan degree). (5) Materi, pada bagian ini pada Lembar Kerja Siswa dikembangkan sesuai dengan karakteristik peserta didik dan konten pada materi tersebut, menggunakan unsur teks, dan gambar. (6) Tes formatif, sesuai dengan peran Lembar Kerja Siswa sebagai media pembelajaran menggunakan kuis berupa essay, untuk mengukur kompetensi siswa sesuai dengan tujuan pembelajaran. (7) Penilaian, pada bagian ini dilakukan secara manual untuk melatih kemampuan berpikir peserta didik dalam menjumlahkan nilai yang dihasilkan dari kuis yang mereka dapatkan. Dengan demikian, LKS dapat mengoptimalkan peran peserta didik melalui penilaian yang bersifat terbuka, jadi peserta didik mengetahui penilaian terhadap hasil yang dikerjakannya.

Validitas Lembar Kerja Siswa Bermuatan Karakter, hasil validitas Lembar Kerja Siswa dari ahli isi mata pelajaran IPA, diketahui bahwa media yang dikembangkan berada pada klarifikasi sangat baik yaitu $100 \%$. Tercapainya kualifikasi sangat baik tersebut dipengaruhi oleh beberapa hal yaitu: (1) dari segi kurikulum sudah sesuai dengan kompetensi dasar, tujuan pembelajaran, dan indikator, (2) dari aspek materi terdapat kemudahan pemahaman mengerjakan praktik /percobaan dalam setiap kegiatan mudah di pahami dan di kerjakan, (3) dari aspek kalimat dan gambar yang disajikan sudah sesuai dengan materi, bahasa yang digunakan dalam penyampaian kegiatan jelas, (4) dari aspek evaluasi sudah sesuai dengan tujuan pembelajaran, dan (5) dari aspek belajar mandiri peserta didik dapat melakukan percobaan tanpa ada pengajar Jika direview ulang, hasil dari ahli isi mata pelajaran IPA melalui kuesioner skala 5 yang telah dinilai, dari tujuh belas kriteria semua kriteria sudah sesuai dengan isi mata pelajaran dan karakteristik siswa.

Hasil review dari ahli media pembelajaran, diketahui bahwa Lembar Kerja Siswa memperoleh persentase tingkat pencapaian 91\% dan berada pada kualifikasi sangat baik. Perolehan kualitas Lembar Kerja Siswa "baik" dikarenakan salah satunya dalam desain pesan teks pada Lembar Kerja Siswa sudah memperhatikan prinsip desain pesan.

Hasil review ahli desain pembelajaran oleh dosen di jurusan Tekonologi Pendidikan, jika direview kembali terdapat sembilan belas kriteria yang tersebar. Kualitas aspek desain pembelajaran terdapat kualifikasi baik dengan presentase $86 \%$ yang kriteria penilaiannya meliputi: a) kurikulum; b) metode; c) pembelajaran (siswa); dan d) penilaian/evaluasi.

Validasi dalam uji coba perorangan mendapat persentase sebesar $98 \%$ dengan kualifikasi sangat baik. Validasi dalam uji coba kelompok kecil memperoleh persentase sebesar 97,5\% dengan kualifikasi sangat baik. Validasi dalam uji coba lapangan memperoleh persentase sebesar 92,7\% dengan kualifikasi sangat baik.

Efektivitas Lembar Kerja Siswa dengan model pengembangan Hannafin and Peck, Efektivitas pengembangan Lembar Kerja Siswa yang dilakukan dengan metode tes pilihan ganda diukur dengan memberikan lembar soal pilihan ganda terhadap 30 orang siswa kelas IV di SD Negeri 5 Kampung Baru melalui pretest dan posttest. Data skor pretest dan posttest 30 orang siswa tersebut, maka dilakukan uji-t untuk sampel berkorelasi. Rata-rata skor pretest siswa adalah 37,8 dan rata-rata skor posttest siswa adalah 85,0 Setelah dilakukan penghitungan secara manual diperoleh Hasil analisis uji-t diperoleh $\mathrm{t}$ hitung $=20,04$, sedangkan $\mathrm{t}$-tabel dengan $\mathrm{db}=(\mathrm{n} 1+\mathrm{n} 2)-2=58$ pada taraf signifikansi $5 \%=1,67155$. Hasil ini menunjukkan bahwa $\mathrm{t}$-hitung $>\mathrm{t}$ table. Oleh karena itu dapat dinyatakan bahwa H0 yang menyatakan bahwa LKS dengan model pengembangan Hannafin and Peck efektif diterapkan dalam mata pelajaran IPA siswa kelas IV Tahun Pelajaran 2019/2020 di SD Negeri 5 Kampung Baru. Dilihat dari konversi hasil belajar di kelas IV SD Negeri 5 Kampung Baru, skor rata-rata posttest peserta didik 85,0 berada pada kualifikasi sangat baik.

Menggunakan Lembar Kerja Siswa dengan model pengembangan Hannafin and Peck dapat memberikan pengalaman baru bagi peserta didik dalam proses pembelajaran di kelas, serta dengan LKS dapat membantu guru dalam menyampaikan materi dapat lebih maksimal diterima oleh peserta didik, dan dapat membantu siswa dalam proses belajar yang disampaikan melalui media LKS. 


\section{Simpulan}

Lembar Kerja Siswa (LKS) dengan model pengembangan Hannafin and Peck ini berisikan tentang selalu berhemat energi yang di kemas dalam bentuk buku cetak dengan konten gambar dan teks agar lebih menarik. Dalam pengembangn media interaktif ini digunakan model pengembangan Hannafin and Peck dengan pengembangan produk terdiri dari 3 tahapan, yaitu tahap Analisis (Analysis), Tahap perancangan (Design), Tahap pengembangan (Development), Tahap implementasi (Implementation), Tahap evaluasi (evaluation). Kelayakan Lembar Kerja Siswa (LKS) ini berdasarkan uji ahli diperoleh hasil sebagai berikut (1) uji ahli isi mendapakan nilai $100 \%$ dengan kualifikasi sangat baik, (2) ahli media pembelajaran mendapatkan nillai $91 \%$ dengan kualifikasi baik, (3) dan uji ahli desain pembelajaran mendapatkan nilai $86 \%$ dengan kualifikasi baik. Pada uji coba produk diperoleh hasil sebagai berikut (1) uji peorangan mendapatkan nilai $98 \%$ dengan kualifikasi sangat baik, (2) uji kelompok kecil mendapatkan niai 97,5\% dengan kualifikasi sangat baik, dan (3) uji lapangan mendapatkan nilai $92,7 \%$ dengan kualifikasi sangat baik), dengan perolehan nilai dari uji para ahli dan uji coba perorangan, kelompok kecil, dan lapangan, pengembangan LKS secara keseluruhan memperoleh persentase sangat baik dan bisa digunakan lebih lanjut. Hasil analisis uji-t diperoleh t hitung $=20.04$, sedangkan $\mathrm{t}_{\text {-tabel }}$ dengan $\mathrm{db}=(\mathrm{n} 1+\mathrm{n} 2)-2=58$ pada taraf signifikansi $5 \%=1,67155$. Hasil ini menunjukkan bahwa $\mathrm{t}_{\text {-hitung }}$ $>$ t- tabel .Oleh karena itu dapat dinyatakan bahwa H0 yang menyatakan bahwa LKS dengan model pengembangan Hannafin and Peck efektif diterapkan dalam mata pelajaran IPA siswa kelas IV Tahun Pelajaran 2019/2020 di SD Negeri 5 Kampung Baru.

\section{Daftar Pustaka}

Undang-undang No. 20 Tahun 2003 tentang Sistem Pendidikan Nasional. 2003. Departemen Pendidikan Nasional.

Arsyad, A. 2015. Media Pembelajaran. Jakarta: PT. RajaGrafindo Perada.

Asyhar, Rayandra. 2012. Kreatif Mengembangkan Media Pembelajaran. Jakarta: Refrensi Jakarta

Agung, A. A. G. 2014. Buku Metodologi Penelitian Pendidikan. Malang: Aditya Media Publishing.

Ernawati, Andi. Misykat, M. Ibrahim,A,A. 2017. Pengembangan Lembar Kerja Siswa Berbasis Multiple Intelligences Pada Pokok Bahasan Substansi Genetika Kelas Xii Ipa Sma Negeri 16 Makassar. Jurnal Biotek Volume 5,No 2, Desember. Terdapat pada http://journal.uin alauddin.ac.id /index. php/biotek/article/download/4276/3999 (Diakses tanggal 27 April 2019).

Fathurrohman, P. H., dkk. 2013. Pengembangan Pendidikan Karakter. Bandung: PT Reflika Aditama.

Febrianti, Erni. Sri,H. Kasmadi,I,S. 2015. Pengembangan Lembar Kerja Siswa (LKS) Materi Larutan Penyangga Model Problem Based Learning Bermuatan Karakter Untuk Siswa SMA. Journal of Innovative Science Education 4 (1). Terdapat pada https:// journal. Unnes .ac.id / sju / index . php/jise/article/view/6890/5841 (Diakses tanggal 27 April 2019).

Sudarma, K. Tegeh, T. \& Prabawa, D. A. P. 2015. Desain Pesan Kajian Analisis Desain Visual Teks dan Image. Yogyakarta: Graha Ilmu

Tegeh, I Made \& Kirna, I Made. 2010. Metode Penelitian Pengembangan Pendidikan. Singaraja: Universitas Pendidikan Ganesha.

Tegeh, I Made. dkk. 2014. Model Penelitian Pengembangan. Singaraja: Yogyakarta Graha Ilmu.

Zubaedi. 2011. Desain Pendidikan Karakter (Konsepsi dan Aplikasinya dalam Lembaga Pendidikan). Jakarta: Prenada Media Group 